\title{
Do corpus mysticum da Igreja à persona mystica do Estado: Carl Schmitt e Ernst Kantorowicz
}

From corpus mysticum of the church to the persona mystica of the

State: Carl Schmitt and Ernst

\author{
António Bento*
}

Universidade da Beira Interior, Covilhã, Portugal

\section{Resumo}

Este artigo compara o tratamento que Carl Schmitt e Ernst Kantorowicz fazem daquela ficção jurídica a que a teologia política medieval cristã chamou o «corpo místico de Cristo». Mediante esta comparação, o artigo discute e analisa os conceitos teológicos de «corporificação» e «mediação» e os conceitos jurídicos de «personificação» e «representação». Apoiada nos contributos de ambos os autores, a elucidação histórica e política destes conceitos permitirá, por sua vez, o esclarecimento contextualizado da noção de «lgreja visível» e o aprofundamento teórico do debate moderno em torno do problema da secularização.

Palavras-chave: Mediação. Representação. Corpo. Personificação. Visibilidade.

* AB: Doutor, e-mail: antobento@sapo.pt 


\section{Abstract}

This article compares the treatment made by Carl Schmitt and Ernst Kantorowicz of that juridical fiction which medieval political theology called the «mystic body of Christ». By means of this comparison, the article discusses and analyses the theological concepts of «bodyfication» and "mediation» as well as the legal concepts of "personification» and "representation». With support from both authors, the historic and political elucidation of these concepts will in turn provide a contextualized clarification of the notion of "Visible Church" allowing further theoretic deepening of the modern debate around the problem of secularization.

Keywords: Mediation. Representation. Body. Personification. Visibility.

\section{Parte I-Carl Schmitt}

Falar de um «corpo místico» da Igreja e de uma «pessoa mística» do Estado é, desde logo, perguntar pela interpenetração e, por vezes, pela osmose de duas formações jurídicas opostas mas complementares: a Igreja e o Estado. Neste artigo ensaiarei uma aproximação às «teologias políticas» de Carl Schmitt e de Ernst Kantorowicz, declinadas nas respectivas concepções da Igreja e do Estado. Da extensa e prolífica obra do primeiro, concentrar-nos-emos, sobretudo, em dois textos: $A$ Visibilidade da Igreja (1917) ${ }^{1}$ e Catolicismo Romano e Forma Política (1923)²; do segundo, seleccionaremos um capítulo nuclear - «A Realeza centrada na lei: corpus mysticum» - dessa obra sem igual que se chama Os Dois Corpos do Rei (1957) ${ }^{3}$.

Acredito que o ponto de conexão que simultaneamente aproxima e distancia os dois autores nas obras analisadas é o modo como um e outro lidam com aquilo a que agora, um tanto ou quanto

\footnotetext{
Cf. SCHMITT, 1917.

Cf. SCHMITT, 1984. Para este texto, servimo-nos da excelente versão disponível em língua portuguesa: SCHMITT, 1998.

Cf. KANTOROWICZ, 1997.
}

Rev. Filos., Aurora, Curitiba, v. 29, n. 47, p. 405-434, maio/ago. 2017 
provisoriamente, chamarei economia política do conceito teológico de «corpus mysticum».

Começaremos por Carl Schmitt. E citamos um trecho de $A$ Visibilidade da Igreja:

Um evento destinado a fazer valer o invisível no visível deve enraizar-se no invisível e aparecer no visível; o Mediador desce porque a mediação só pode dar-se de cima para baixo e não de baixo para cima: a redenção consiste em que Deus se tornou homem (não em que o homem se tornou Deus). A similitude sempre recorrente, "tal como Cristo tinha um corpo real, também a Igreja deve ter um corpo", contém efectivamente um argumento da mais alta dignidade, pois revela uma identidade na estrutura lógica de ambos os processos, e, restituindo com uma imagem concreta o resultado de uma reflexão extrema, expressa a grandiosa estrutura da própria "mediação" que constitui a essência da Igreja. Não se pode acreditar que Deus se fez homem sem acreditar também que, enquanto o mundo perdurar, existirá também uma Igreja visível. Todas as seitas espiritualistas que volatilizaram o conceito de Igreja enquanto comunidade visível de cristãos observantes num corpus mere mysticum, duvidaram, no fundo, da humanidade do Filho de Deus e falsificaram a realidade histórica da Encarnação de Cristo, transformando-a num processo místico e irreal (SCHMITT, 1917, p. 75).

Além de uma observação inicial sobre o carácter específico da mediação eclesial, que é feita "de cima para baixo", por oposição, subentende-se, ao tipo de mediação configurada pelo Estado, que opera "de baixo para cima", o núcleo íntimo desta reflexão de Carl Schmitt está no modo como o autor opõe ao conceito de Igreja enquanto «um mero corpo místico» um conceito de Igreja como «corpo visível». Na medida, portanto, em que Carl Schmitt admite o símile do «corpo» para designar o ser político eclesiástico, é da oposição entre um «corpo místico» da Igreja e um «corpo visível» da Igreja que me vou ocupar.

O meu propósito, num primeiro momento, é averiguar se, enquanto formação jurídica, a Igreja pode ser simultaneamente detentora dos títulos de mediadora autorizada do corpo de Cristo no mundo e de representante política da sua pessoa, sem que o corpo e a pessoa, que o mesmo é dizer, sem que a mediação e a representação entrem em conflito. 
Tal busca passa também por inquirir se existe uma continuidade histórica efectiva entre os conceitos de mediação e de representação, ou se, pelo contrário, a partir de um certo momento no tempo, estes conceitos se sobrepuseram, vindo, finalmente, a desembocar numa antítese sem qualquer espécie de síntese possível.

Ora, a mediação é um conceito eminentemente teológico, ao passo que a representação é um conceito fundamentalmente jurídico. Com efeito, na representação um dos termos da relação - o representante - está pelo outro, no lugar do outro ou em vez do outro: o representado. Recordo, a propósito, uma definição sumária do conceito jurídico de «representação» tal como Schmitt a formula na sua Doutrina da Constituição (1928): «Representar significa: através de um ser publicamente presente tornar visível e tornar presente um ser invisível. A dialéctica do conceito está em que o invisível seja pressuposto como ausente e, no entanto, ao mesmo tempo, seja tornado presente» (SCHMITT, 1993, p. 209-210).

Apesar das semelhanças existentes entre a definição schmittiana do «conceito» de «representação», num texto "puramente" jurídico como o da Doutrina da Constituição (1928), e a teoria eclésio-juridica da «representação», previamente avançada em Catolicismo Romano e Forma Política (1923), a verdade, porém, é que neste último texto (um opúsculo de apologética anti-protestante profundamente marcado por um pathos anti-liberal, tanto no sentido político como no sentido económico do termo «liberal») a «ideia» de «representação», mais do que um «conceito» de significado fundamentalmente jurídico, está intrinsecamente marcada por um halo teológico, consagrado por um recurso a termos como «transcendência», «autoridade», «institucionalismo», «personificação».

Sob a perspectiva de Schmitt, tornar visível a «ideia» do catolicismo romano é uma tarefa inexaurível, que necessariamente implica a «transcendência», uma vez que é próprio da Igreja uma referência específica ao «transcendente», que pela sua própria natureza não é visível. Deste ponto de vista, é sempre uma realidade invisível e não presente que se mostra na «representação», e que por isso a torna não apenas possível, mas ao mesmo tempo necessária. É a «representação» que 
dá corpo à «ideia» e que a torna visível. Referida à Igreja, a «representação» está ligada à necessidade de tornar tangível, palpável e visível aquilo que pela sua própria natureza o não é:

A ideia da representação [por oposição ao «pensar económico» liberal] é tão dominada pelo pensamento da autoridade pessoal, que tanto o representante como o representado têm de afirmar uma dignidade pessoal. Ela não é nenhum conceito pragmático. Num sentido eminente, só uma pessoa pode representar - diferenciando-se da simples "delegação do lugar" -, e representar uma pessoa autoritária ou uma ideia que, na medida em que é representada, precisamente se personifica. Deus ou, na ideologia democrática, o povo, ou ideias abstractas como liberdade e igualdade, são o conteúdo pensável de uma representação, mas não a produção e o consumo. A representação dá à pessoa do representante uma dignidade própria, porque o representante de um valor elevado não pode não ter valor (SCHMITT, 1998, p. 35) ${ }^{4}$.

Não entraremos aqui na discussão do problema da «representação» em toda a sua extensão e na complexidade (dir-se-ia mesmo esoterismo) em que ele se dá a ver na obra de Carl Schmitt. Limitamo-nos a fazer uma análise sumária com vista ao esclarecimento do nosso argumento. Observamos, no entanto, que tem razão, neste particular, Carlo Galli, quando, numa obra a vários títulos notáveis, afirma que «na complexidade do conceito schmittiano de representação está em jogo a compreensão de todo o pensamento de Schmitt» (GALLI, 1996, p. 240).

Diferentemente da representação, na mediação não há substituição de um termo pelo outro, mas antes a presença simultânea de dois termos mediante a interposição de um terceiro, que, não anulando a oposição e a tensão entre os dois termos iniciais, os põe necessariamente em relação. O que isto, a meu ver, significa é que com a passagem da mediação à representação, transitamos de um modelo ternário para um modelo binário, e de um conceito teológico para um conceito jurídico. Pode, por conseguinte, dizer-se que a mediação corresponde, grosso modo, a um «corpo» ou uma «corporificação», enquanto a representação corresponde a

4 Para uma leitura do carácter «transcendente» da «representação» como raiz da «teologia política» de Carl Schmitt, veja-se 0 esclarecedor trabalho de DUSO, 2005, p. 174-195. 
uma «pessoa» ou uma «personificação». Significa isto que a passagem do «corpo» de Cristo à «pessoa» de Cristo, ou a passagem da «corporificação» de Cristo à «personificação» de Cristo, é uma passagem do teológico ao jurídico. Ora, esta passagem não se faz sem um certo atrito.

E é precisamente aqui que surge o núcleo duro do problema histórico da "visibilidade" da Igreja, que é no fundo, como veremos, o problema da invisibilidade do «corpo» de Cristo na «pessoa» de Cristo. Dir-se-ia que se trata aqui da incompletude ou da insuficiência do jurídico face ao teológico, ou, dito de outro modo, da dependência da representação face à mediação.

Para antecipar um pouco o núcleo do meu argumento, direi que, numa certa medida, o aparecimento da noção medieval do «corpo místico» de Cristo, enquanto problema eminentemente teológico-político, se deve ao facto de aquela noção se dar originariamente a ver sobretudo como uma reacção, ou como uma resposta, à perda de visibilidade do «corpo» «histórico» e «sacramental» de Cristo, uma vez este configurado na «pessoa» jurídica da Igreja. Sob este aspecto, o «místico» pode talvez entender-se como uma resposta à perda de "visibilidade" do «corpo» histórico comunitário da Igreja, paulatinamente substituído, na recta final da Baixa Idade Média, pela «pessoa» jurídica do Estado. É como se a vocação "natural" da Igreja para a «mediação» não pudesse dar-se, afirmar-se e permanecer sem o apoio da «representação».

Com efeito, nos primeiros tempos da formação da Igreja, e de acordo com a tradição teológica cristã, os três corpos de Cristo - o corpo «histórico», o corpo «sacramental» e o corpo «eclesial» - são objecto de um recorte que passa entre o primeiro e o segundo corpo, ao passo que alguns séculos mais tarde - já no decorrer do século XII - este recorte, ou essa cesura, se efectua entre o segundo e o terceiro corpo. Evoco, sobre este assunto, o excelente estudo do teólogo católico Henri de Lubac, que, na minha opinião, capturou e analisou muito bem este problema na obra Corpus mysticum. L'eucharistie et l'Eglise au Moyen Age (1944): «Tal é, em resumo, o facto que domina toda a evolução das teorias eucarísticas» (LUBAC, 2009, p. 288).

Ora, o que aqui acontece é que uma nova fórmula binária, que se traduz numa relação de oposição entre o «corpus verum» (ou corpo real 
de Cristo) e o «corpus mysticum» de Cristo, se substitui lentamente à tradicional fórmula ternária, sendo que, ao mesmo tempo em que se dá essa substituição, o conteúdo da oposição entre «corpus verum» e «corpus mysticum» é intensificado e duplicado pela oposição entre «invisível» e «visível». Dir-se-ia que se trata de uma primeira grande guinada para a visibilidade, e que é aqui que começa a secularização do cristianismo, isto é, a constituição estatal da Igreja.

Com efeito, a Igreja deixa agora de significar o «corpus verum» e passa a significar o «corpus mysticum» de Cristo. Paradoxalmente, a Igreja será daí em diante tanto mais "visível" quanto mais ela se reivindicar do e identificar com o «corpus mysticum» de Cristo.

Seja como for, esse corpo de que a Igreja é o significante, o «corpus Christi», é sempre, até ver... um corpo «histórico» desaparecido e um corpo «real» invisível e ausente que apenas o sacramento e consagração do pão e do vinho tornam visível e presente. A invisibilidade originária deste «corpo» é um fantasma, ou antes, uma alucinação, que persegue todos os que sofrem da dor de uma ausência de corpo e que, congregados nessa dor, fundam a sua comunhão ou comunidade - a Igreja ${ }^{5}$. Creio que deste ponto de vista se pode dizer que a secularização (medieval) se dá por efeito de uma espécie de a-historicidade, ou mesmo anti-historicidade, do cristianismo, por efeito de uma espécie de défice histórico de corpo.

Desaparecido, o corpo «real» de Cristo tornou-se invisível. E a "invisibilidade" da Igreja não é senão a "invisibilidade" do "corpus verum» de Cristo. Por isso deve a Igreja, precisamente enquanto «corpo místico de Cristo», ser sumamente visível; e daí também a sua obsessão com o visível: "fazer ver o invisível para fazer crer no visível".

Com efeito, pode-se dizer que a partir de meados do século XII, de maneira progressiva, mas irreversível, a estrutura binária do «corpo real» vs «corpo místico» de Cristo se sobrepõe à estrutura ternária dos corpos «histórico», «sacramental» e «eclesial» de Cristo.

5 Como um dia observou Franz Kafka acerca da relação que os mártires mantêm com o corpo, pensando eventualmente na crucificação de Jesus de Nazaré - : «0s mártires não menosprezam o corpo. Deixam que seja elevado na cruz. Neste ponto estão de acordo com os seus adversários» (KAFKA, 1992, p. 19). 
Antes, porém, de passar à análise desta tese (que Henri de Lubac e Ernst Kantorowicz, cada um a seu modo, subscrevem), dela extraindo todas as consequências, devo primeiro dedicar algumas palavras à evolução da expressão medieval «corpus mysticum» de Cristo. De acordo com os autores que se consagraram ao estudo deste assunto, convencionou-se reconhecer que até meados do século XII a expressão «corpus mysticum» qualificava a «Eucaristia». Mas, precisamente, daí em diante, «corpus mysticum» passará a qualificar a própria «Igreja». Reciprocamente, o «corpus verum», que até aí qualificara a «Igreja», passará a partir de então a qualificar a «Eucaristia». Nesta complexa operação de transmutação de propriedades, os adjectivos «mysticus» (oculto) e «verum» (verdadeiro, real e como tal cognoscível) trocam, por assim dizer, de posição. Este problema, parecendo à primeira vista simples, é, no fundo, um problema relativamente complexo. Temos, pois, o seguinte esquema:

Até 1150: Corpus mysticum de Cristo = Eucaristia

Corpus verum de Cristo $=$ Igreja

Após 1150: Corpus mysticum de Cristo = Igreja

Corpus verum de Cristo $=$ Eucaristia

Mas, o que significa verdadeiramente este quiasma? Bem vistas as coisas, a expressão «corpus verum» ou «corpo real de Cristo» não é nem menos "mística" nem menos fictícia do que a expressão «corpus Christi mysticum». E também não se trata de saber quantas «pessoas» cabem num «corpo» nem de quantos «corpos» necessita uma «pessoa» para se constituir como «pessoa». O interessante - e problemático - é procurar saber o que ocorre quando se transita do «corpo» para a «pessoa».

Comecemos, para já, pelo «corpus Christi mysticum». O que é que o credo teológico cristão nos diz do «corpo místico» de Cristo? Em primeiro lugar, que esse «corpo», que brilha pela sua ausência, é objecto de uma busca permanente. Ele permanece, por assim dizer, em parte incerta e por encontrar. Com efeito, a doutrina teológica cristã começa por chamar a nossa atenção para o facto de faltar um «corpo» que se procura de modo obsessivo. A busca deste «corpo» dá-se numa espécie de 
peregrinação em direcção a um lugar marcado por um desaparecimento. Digamos que «há um discurso - um Logos, uma teologia, etc. - mas que falta um corpo» (CERTEAU, 1982, p. 108) a esse discurso. É, pois, necessário, que o espírito encontre um corpo, é necessário que o discurso "encarne" e dê lugar a uma verdade. Daí a fórmula Hoc est corpus meum («Este é o meu corpo»). Na verdade, esta afirmação da Eucaristia limita-se a recordar um desaparecimento ao mesmo tempo que reclama uma efectividade - litúrgica e sacramental - que nasce e se funda precisamente nesse desaparecimento, nessa falha faltosa do «corpo».

O que isto, no fundo, quer dizer é que o problema inicial do «místico» surge com uma pergunta: onde está o «corpo» de Cristo? É esta pergunta que se encontra na raiz da doutrina ecleseológica do «corpo místico de Cristo». Assim, diante do túmulo vazio, Maria Madalena afirma: «Não sei onde o puseram». E, ignorando que se dirige ao próprio ressuscitado, interroga aquele que passa: «Se foste tu que o levaste [ao corpo] diz-me onde o puseste» ${ }^{6}$. Ora, é esta busca permanente e incessante que identifica e organiza todo o discurso apostólico. Como observa Michel de Certeau num excelente estudo consagrado à mística medieval que temos vindo a acompanhar, dir-se-ia que o corpo de Jesus sofre do problema de "ter existido antes", de "estar momentaneamente inacessível algures", e de "regressar" mais tarde. Consequentemente, nunca é demais insistir que o «corpo místico» dos apóstolos ou o «corpus Ecclesiae mysticum», é, portanto, um «corpo» que falta e que, como tal, se trata de um «corpo» que deve ser procurado. Como já observamos,

6 Cf. Evangelho de João, 20, 13 e 15. Num magnífico conto intitulado The Man Who Died, o escritor D. W. Lawrence ficciona a situação de um Cristo corporalmente "ressuscitado", vagueando, moribundo, pelos arredores de Jerusalém. Lawrence descreve os dias que se seguiram imediatamente à sobrevivência de Jesus após a crucificação. Os seus carrascos haviam-no despregado demasiado cedo da cruz: «'Não tenhas medo', disse o homem da mortalha [ao camponês que 0 acolhera em sua casa e que Ihe tratara das feridas e 0 ajudara na mudança das ligaduras]. 'Não estou morto. Sepultaram-me cedo demais. Então ergui-me. Mas, se me descobrem, farão o mesmo outra vez'». Neste seu conto, Lawrence ocupa-se de um Cristo convalescente que, sobrevivendo à crucificação, procura daí en diante a solidão e 0 anonimato entre os homens, recusando obstinadamente a cupidez do amor cristão que ele próprio fundara: já nada quer saber do ardor e do ímpeto de dar sem nada receber (LAWRENCE, 1988, p. 125-168). Uma leitura muito estimulante deste extraordinário conto de D. H. Lawrence é feita por Gilles Deleuze em "Nietzsche et Saint Paul, Lawrence et Jean de Patmos" (DELEUZE, 1993, p. 50-70). 
este «corpo» que falta, este corpo em falta, configura em si mesmo um desaparecimento fundador. Daí que Michel de Certeau possa afirmar:

O cristianismo institui-se à volta da perda de um corpo, da perda do corpo de Jesus, duplicada pela perda do "corpo" de Israel, de uma "nação" e da sua genealogia. [...] Na tradição cristã, uma privação inicial de corpo não cessa de suscitar instituições e discursos que são os efeitos e os substitutos dessa ausência: corpos eclesiásticos, corpos doutrinais, etc. (CERTEAU, 1982, p. 109-111).

Cabe agora referir que a oposição, já perceptível na Baixa Idade Média, entre o «corpus verum» e o «corpus mysticum» da Igreja se reforça e se intensifica com a Reforma: «Jesus tem um corpo real e um corpo místico na terra... Nós aderimos ao seu corpo real pela comunhão na Eucaristia, e ao seu corpo místico pela comunhão na Igreja» - diz Pierre de Bérulle, o cardeal e teólogo oratoriano francês que no século XVII se consagrou à conversão dos protestantes. «Esta oposição» - sublinha ainda Michel de Certeau - «atravessa os próprios meios católicos que, levados pela apologética anti-protestante, tanto sublinham o carácter exterior e visível da Igreja, como buscam no 'espiritualismo' um contraponto à politização do Estado ou do 'mundo'» (CERTEAU, 1982, p. 127).

Uma vez os fios teológicos do problema em análise desemaranhados, cabe-nos agora perguntar: em que consiste, afinal, o núcleo do problema histórico da "visibilidade" da Igreja de que se ocupa Carl Schmitt num ensaio homónimo? Para dar adequadamente conta desta questão, seria porventura necessário, antes de mais, situar a apologética anti-protestante de Schmitt num contexto epocal simultaneamente mais vasto e mais concreto, que se traduz, primeiro, no problema da relação do cristianismo com a esfera política na nova configuração institucional instaurada pela República de Weimar, e, depois, nas questões que se levantam com a ascensão de Hitler ao poder. Todavia, por muito importantes e efectivas que estas questões se nos apresentem, não é este nem o momento nem a ocasião para a sua dilucidação ${ }^{7}$.

7 Sobre o contexto intelectual, religioso e político na Alemanha e na França no período entre as duas grandes guerras, veja-se COLONGE, 2009, p. 25-30. Veja-se ainda BOURDIN, 2007, p. 7-43. 
Que baste por ora dizer que, além de a Rudolph Sohm, o autor com quem Schmitt polemiza directamente em $A$ visibilidade da Igreja, é sobretudo ao grande historiador da Igreja e teólogo luterano Adolf von Harnack que Schmitt vai buscar alguns dos elementos mais decisivos da sua reflexão sobre a Igreja. Harnack, com efeito, é o autor de um monumental Lehrbuch der Dogmengeschichte (1889-1900) e de um conjunto de dezesseis conferências sobre o cristianismo proferidas na Universidade de Berlim nos anos 1899-1890, coligidas sob a forma de livro em Das Wesen des Christentums. Do nosso ponto de vista, acreditamos que toda a estrutura argumentativa de Schmitt em A Visibilidade da Igreja é uma resposta circunstanciada ao modo como Adolf von Harnack apresenta - e critica - o uso que o catolicismo romano faz do Evangelho:

Em primeiro lugar - uma palavra sobre este ponto bastará - tudo o que constitui a organização visível da Igreja, com as suas pretensões à dignidade divina, não tem qualquer relação com o Evangelho. Não é de uma deformação que aqui se trata, mas de uma perversão total: a religião perde-se num caminho falso. A pretensão de que Cristo fundou um Reino, que é a Igreja Romana, e que dotou essa Igreja com um gládio, aliás, com dois gládios, espiritual e temporal, constitui uma verdadeira secularização do Evangelho e não pode ser legitimada por esse pretexto vão de que Cristo deve reinar sobre a humanidade. O Evangelho diz: "o reino de Cristo não é deste mundo", e esta Igreja instituiu um reino "neste mundo"; Cristo exige que os seus discípulos sirvam, não que governem, e os padres governam o mundo; Cristo liberta os seus discípulos das religiões políticas e cerimoniais, para os pôr diante da face de Deus; e aqui, pelo contrário, o homem está ligado por cadeias indissolúveis a uma instituição terrestre, à qual é necessário que ele obedeça: somente então poderá aproximar-se de Deus. Em Roma, outrora, os cristãos derramaram o seu sangue porque recusavam adorar o Imperador e rejeitavam, com desdém, a religião política; em Roma, hoje, se não adoram, propriamente falando, um soberano deste mundo, entregaram pelo menos as suas almas ao poder soberano do Papa-Rei. O catolicismo romano enquanto Igreja visível, enquanto Estado fundado na lei e na violência, nada tem que ver com o Evangelho. Pouco importa que este Estado tome de empréstimo do Evangelho uma auréola divina, 
e que essa auréola lhe seja extraordinariamente útil; não será isso que modificará o nosso juízo (HARNACK, 1907, p. 312-314).

Uma vez feita esta breve e, sem dúvida, incompleta contextualização, cumpre-nos agora que referir que é directamente na obra do protestante Adolf von Harnack que Carl Schmitt vai beber o afortunado e oportuno conceito de uma «complexio oppositorum», entendida como a forma política por excelência do catolicismo romano. Cito novamente Adolf von Harnack:

Pela sua própria organização, esta Igreja [o catolicismo romano] possui como nenhuma outra a capacidade de se adaptar às contingências históricas. [...] E foi assim que se formou, no catolicismo ocidental, essa formidável complexio oppositorum, que quer que a Igreja do rito, da lei, da política e do imperialismo, seja também a Igreja que põe em acção uma experiência e uma doutrina do pecado e da graça, mais pessoal, mais delicada, mais espiritual do que qualquer outra. É querer unir o que há de mais material com o que há de mais íntimo. Uma tal união não podia no início dar-se sem dificuldades; a desarmonia interior e a oposição deveriam em breve eclodir: a história do cristianismo ocidental abunda em casos destes. No entanto, esses contrários são conciliáveis até um certo ponto; pelo menos podem reunir-se num mesmo homem. E disso temos nós um testemunho que não é outro senão o de Santo Agostinho, que foi também um homem de Igreja resoluto, e que trabalhou com todas as suas forças para aumentar o prestígio e o poder da Igreja visível, assim como para aperfeiçoar a sua organização (HARNACK, 1907, p. 306 e 310).

«Complexio oppositorum» e «Igreja visível». Eis, como se sabe, duas expressões a que Carl Schmitt procurará atribuir um sentido muito peculiar nesses textos apologéticos que são A Visibilidade da Igreja e Catolicismo Romano e Forma Política.

Com efeito, há na «complexio oppositorum», que segundo Carl Schmitt caracteriza a forma política do catolicismo romano, uma «multilateralidade», uma «ambiguidade» e até um «hermafroditismo» que vão muito além de um qualquer mero esforço de «síntese das antíteses» (SCHMITT, 1998, p. 26). Porém, o traço que melhor caracteriza 
este conceito, como bem observou Adolf von Harnack, é, sem dúvida, a sua indeterminação e «elasticidade», a sua capacidade, enfim, para dar forma jurídica às oposições. Daí que Schmitt, justiça seja feita à sua astúcia de polemista, o apresente como a condição de possibilidade de uma teoria jurídica da «representação», à qual ele vincula, não sem uma certa liberdade de interpretação, uma teoria dogmática da decisão. Na verdade, o uso que Carl Schmitt faz da noção harnackiana de «complexio oppositorum» é um modo engenhoso de transformar o ternário em binário, uma vez que, de um ponto de vista teológico, é a verdade dogmática da encarnação - «a mais espantosa complexio oppositorum» (SCHMITT, 1998, p. 29), observa Schmitt - que configura a estrutura originária da «mediação» que caracteriza a essência da Igreja. Schmitt transforma, pois, aquilo que é originariamente da ordem da «mediação» em algo que é capturado e instrumentalizado numa pura lógica da «representação». Resta, contudo, saber se o conceito jurídico de «representação» se adequa ao que o mesmo Schmitt, em $A$ visibilidade da Igreja, chama a "grandiosa estrutura da própria "mediação" que constitui a essência da Igreja» (SCHMITT, 1917, p. 75).

Cristo, argumenta Carl Schmitt, é o mediador: só ele faz valer o invisível no visível; Cristo radica no invisível e, contudo, manifesta-se no visível. Por conseguinte, a "visibilidade" da Igreja como "visibilidade" da mediação originária de Cristo nasce da encarnação humana de Jesus. Por isso, pode também dizer-se que a Igreja enquanto instituição é o medium das condições de visibilidade da própria encarnação - que Schmitt qualifica como «acontecimento histórico único».

$\mathrm{Na}$ verdade, porém, não basta afirmar que a "visibilidade" da Igreja nasce - directamente, magicamente - da encarnação humana de Cristo. De igual modo, que o «corpo» da Igreja, à semelhança do «corpo» de Cristo, torne visível o invisível, não significa a reivindicação do visível a qualquer preço e sem condições. Recordemos, a propósito, as palavras de Carl Schmitt:

A visibilidade da Igreja repousa em algo que é invisível e o conceito de Igreja visível é em si mesmo algo invisível. E assim como toda a realidade, na medida em que se funda em Deus, perde a sua realidade pelo 
facto de que Deus se torna na única e verdadeira realidade, também a verdadeira visibilidade da Igreja se torna invisível, e não há nenhuma Igreja invisível que não seja visível, e nenhuma Igreja visível que não seja invisível. É assim que ela pode estar neste mundo sem ser deste mundo (SCHMITT, 1917, p. 75).

A verdade, porém, é que podemos sempre colocar os problemas schmittianos da invisibilidade do visível e da visibilidade do invisível de um outro modo: com a mediação da Igreja, que é já, em si mesma, uma mediação de uma mediação, a saber, a mediação de Cristo encarnado, tratar-se-ia não tanto de tornar visível o invisível, mas de obviar ao puro desaparecimento do invisível mediante o visível. Na verdade, é da mediação desta "invisibilidade" - e, em primeiro lugar, da mediação da "invisibilidade" do "corpo de Cristo» - que a Igreja retira toda a sua autoridade e competência dogmática. E é essa a razão porque podemos afirmar que não há uma genuína autoridade e, por maioria de razão, uma autoridade especificamente eclesial, sem alguma forma de "invisibilidade" 8 .

Resta agora apurar se o carácter binário da «representação» se ajusta ao carácter ternário da «mediação», e se é exactamente do mesmo Cristo que estamos a falar quando declinamos a sua identidade sob a forma de um «corpo» (teológico) ou sob a forma de uma «pessoa» (jurídica). Do nosso ponto de vista, uma tal assimilação só se torna possível à custa de um uso ad hoc e inadequado dos conceitos, tornados operativos fora do âmbito que determina a sua validade semântica, respectivamente a teologia e a jurisprudência.

É que uma coisa é a «pessoa» de Cristo, outra, bem distinta, é o «corpo» de Cristo. Evidentemente, não há «personificação» sem alguma

8 Nesta mesma época, a doutrina da "Igreja visível" de Erik Peterson, um autor protestante que se converteu ao catolicismo em 1930, capta de maneira acurada e rigorosa a atmosfera e o espírito do tempo que marcam os debates teológicos entre protestantes e católicos ocorridos na Alemanha pré-hitleriana: «A autoridade da Igreja, que representa Jesus depois da sua ascensão, é uma autoridade emprestada por Jesus». "Se a Igreja pode representar o Cristo é porque o Cristo está ausente e porque a Igreja, pela sua essência, é visível, tão visível como, justamente, é visível o corpo». Cf. Erik Peterson, “Was ist Theologie?" [1925]: PETERSON, 1994, p. 15, nota 24, e p. 22. Note-se que é enquanto luta contra o hitlerismo que Peterson se converte ao catolicismo e clama por uma "Igreja visível". 
forma de «representação», do mesmo modo que não existe «mediação» sem alguma forma de «corporificação». Aliás, precisamente por ser intrinsecamente teológica, a linguagem da «mediação» não pode deixar de implicar, de um modo ou de outro, um ser de natureza gémea - Cristo. O ponto está em que Carl Schmitt pretende que a Igreja «representa o próprio Cristo pessoalmente, o Deus que se tornou homem na realidade histórica», que a Igreja «representa a pessoa de Cristo» (SCHMITT, 1998, p. 33, 42). Sob esta perspectiva, é, sem dúvida, significativo que o jurista Carl Schmitt afirme que a Igreja «representa 'a partir de cima'» (SCHMITT, 1998, p. 39), em vez de sustentar, como seria talvez fundado esperar de um Carl Schmitt raciocinando como teólogo, que a Igreja «medeia "a partir de cima"». Pois o que significa exactamente "Corpus Ecclesiae Mysticum» senão o império da «mediação»?

Na verdade, a Igreja é tanto mais "visível" quanto mais o seu desempenho se aproxima da sua essência: a «mediação». Talvez por isso se deva agora inverter o dito de Carl Schmitt na passagem atrás citada, e a "visibilidade" da Igreja exija, não «a compressão do pneumático no jurídico» (die Einengung des Pneumatischen ins Juridische)» (SCHMITT, 1917, p. 79), mas «a compressão do jurídico no pneumático».

Finalmente, algumas palavras a respeito do nexo de correspondência entre a assim chamada «teologia política» e o modelo cristão da «revelação» que conhecemos sob a expressão «encarnação». A este propósito, deve aqui referir-se que sem o dogma cristão da «encarnação» (Deus feito homem) a própria «secularização» da «teologia política» de que nos fala Carl Schmitt a respeito da estrutura conceptual do Estado moderno se tornaria ininteligível nos seus aspectos mais decisivos, pois, como tivemos a oportunidade de verificar, a própria determinação da «teologia política» de Carl Schmitt mergulha as raízes do seu paradigma na «encarnação» de Cristo enquanto condição de possibilidade da própria «visibilidade da Igreja». A este propósito, coube ao historiador francês Alain Boureau, na sua monografia sobre Ernst Kantorowicz, e precisamente num capítulo em que o autor se interroga sobre a possibilidade de estabelecer um nexo de relação entre os conceitos de «teologia política» de Ernst Kantorowicz e de Carl Schmitt, afirmar assertiva e - quanto a nós judiciosamente - o seguinte: 
Entre 1952 e 1957, a teologia política, para Kantorowicz, tomou um sentido mais vasto e não se limita ao processo de captação absolutista dos recursos da Igreja em matéria de poder; ela designa, no longo prazo, inclusivamente até ao próprio Kantorowicz, a capacidade do homem em fazer viver na terra a coesão dada por uma revelação e particularmente pelo dogma da encarnação, fundador, ele mesmo, da teologia; apenas uma religião do Deus-homem pode criar uma teologia, uma ciência imanente da divindade que não releve de uma revelação suplementar (mística). Na verdade, Kantorowicz inverte o sentido da noção schmittiana: a teologia política não fornece a arma autoritária aos soberanos profanos, já que estes a possuem de antemão; ela obriga-os a jogar com base no modelo da encarnação (a co-presença do imortal e do mortal) para dar uma forma pensada ao seu poder. A teologia política utiliza o momento da encarnação como modelo de uma ficção libertadora que afirma a inalienável e sagrada dignidade do homem aquém e além da sua existência natural (BOUREAU, 1990, p. 166-167).

Este nexo de causalidade entre, por um lado, a «teologia política medieval», a que Ernst Kantorowicz alude no subtítulo da sua obra Os dois corpos do rei, e o modelo cristão da «revelação» entendida como «encarnação», por outro, faz-nos pensar que a célebre definição de Carl Schmitt, segundo a qual «todos os conceitos pregnantes da doutrina moderna do Estado são conceitos teológicos secularizados» (SCHMITT, 1996, p. 43), talvez só adquira a sua plena significação política à luz da ficção jurídica medieval que estabelece que o rex iustus governe more angelico. Uma tal ficção, como bem observou Ernst Kantorowicz, está intrinsecamente ligada à imagem medieval da "perfeição" do poder, quer essa imagem surja sob a sua forma «espiritualizada», quer sob a sua forma «secularizada»:

Saber se o rex iustus ou rex angelicus é mais ou menos operacional que o rex imago Christi ou o rei como lex animata, não é, evidentemente, de modo algum a questão, já que, para uma 'plataforma política' moderna, esses ideais são todos igualmente inúteis. O que aqui importa é a metáfora da 'perfeição', a qual, no século XIII, entrou numa nova fase: a imagem da perfeição ora era espiritualizada (rex angelicus, papa angelicus, imperador messiânico) ora secularizada (lex animata, Iustitia animata, Coroa, Dignidade, etc.), o que não excluía uma mútua sobreposição. 
Não acredito que uma teoria política medieval pudesse funcionar sem uma certa ficção ou sem uma certa 'metáfora da perfeição', e há todas as razões para nos perguntarmos se uma teoria moderna o pode fazer (KANTOROWICZ, 1997, p. 144, nota 168).

Sob esta perspectiva, e tendo em conta tudo o que antes dissemos sobre a «encarnação» e a «visibilidade» da Igreja, podemos talvez arriscar afirmar que se a secularização da metáfora da "perfeição" política existe de modo operativo na modernidade, então talvez o seu começo se dê precisamente com o dogma primigénio da «encarnação». Se acaso esta hipótese se revelar correcta e adequada, então também aquilo a que, não sem alguns equívocos, chamamos "secularização» ${ }^{9}$ dos conceitos teológicos deverá coincidir, de uma forma ou de outra, com o que porventura se poderia chamar a "cristianização" generalizada do poder político no Ocidente. Dito de outro modo, e recuperando a inversão da formulação da tese de Carl Schmitt feita por Jan Assmann: «Todos os conceitos significativos da teologia [cristã medieval] são conceitos políticos teologizados» (ASSMANN, 2015, p. 29) ${ }^{10}$.

\section{Parte II - Ernst Kantorowicz}

Antes de descrevermos o modo como o conceito eclesiástico e corporativista de «corpus mysticum» da Igreja se transladou para a

9 Num estudo consagrado ao impacto da jurisprudência sobre o conceito medieval de «realeza», Ernst Kantorowicz observa 0 seguinte a respeito da metáfora da "secularização»: «Estamos muitas vezes inclinados a falar de 'secularização' do pensamento e das instituições eclesiásticas em conexão com o Estado moderno. Existiu certamente secularização quando, por exemplo, o casamento de Cristo com a Igreja universal, ou o casamento do bispo com a sua igreja local, era, por analogia, transferido para a esfera política e os juristas sublinhavam que o rei estava casado com o seu reino como um 'esposo místico'. Mas encontramos muito pouca dessa 'secularização' no século doze. 0 que então aconteceu foi, não uma secularização do espiritual, mas antes uma espiritualização e santificação do secular». Cf. KANTOROWICZ, 1965, p. 163.

${ }_{10}$ Discutindo 0 sentido e 0 valor desta inversão, Giorgio Agamben observa com razão que a questão de saber se é o político que nasce do espírito da teologia ou se é a religião que nasce do espírito do político é, no fundo, irrelevante: «De certo modo, toda a inversão de uma tese continua secretamente solidária com a tese invertida. Portanto, mais interessante do que tomar partido por uma ou por outra é tentar compreender a relação funcional que, em ambas, liga estreitamente os dois princípios» (AGAMBEN, 2011, p. 203). 
esfera do Estado, vindo a formar um autêntico «corpus mysticum» secular, devemos averiguar e esclarecer os pressupostos políticos que subjazem à formação do conceito de «Corpus Ecclesia Mysticum». Esta noção começa com a bula Unam sanctam, sintetizada e dogmatizada, em 1302, pelo Papa Bonifácio VIII:

Instados pela fé, somos obrigados a crer numa única Igreja, Católica e também Apostólica [...], sem a qual não há salvação nem remissão dos pecados [...], que representa um único corpo místico, cuja cabeça é Cristo e a Cabeça de Cristo é Deus (KANTOROWICZ, 1997, p. 194).

Para Ernst Kantorowicz, o conceito da Igreja como «corpus Christi» remonta a São Paulo. Todavia, o conceito da Igreja como «corpus mysticum Christi», cuja cabeça era Cristo e cuja cabeça visível era o vigário de Cristo, o pontífice romano, era relativamente novo no século XII. Aliás, até ao seu aparecimento no século XII, a expressão «corpus mysticum» não possuía qualquer lastro na tradição bíblica. O termo terá ganho alguma notoriedade com a controvérsia sobre a Eucaristia, quando, no século XII, os teólogos sugeriram que o corpo no qual Cristo tinha sofrido era o seu corpo próprio e verdadeiro (proprium e verum corpus), ao passo que a Eucaristia era o seu «corpo místico». Assim, à medida que progressivamente se põe a ênfase na presença real de Cristo no sacramento - uma doutrina que culminou finalmente no dogma da transubstanciação de 1215, segundo o qual a Eucaristia era oficialmente designada como corpus verum - deu-se o desenvolvimento do termo «corpus mysticum» como uma designação da Igreja nos seus aspectos institucionais e ecleseológicos. Estávamos no começo da chamada "secularização" da Igreja medieval, num momento crítico da história da Igreja. Vejamos o modo como Ernst Kantorowicz apresenta o problema:

Nessa altura, na esfera do dogma e da liturgia, teve origem essa ideia cujos determinantes universais e efeitos finais dificilmente podem ser sobrestimados. Corpus mysticum, na linguagem dos teólogos carolíngios, não se referia de modo algum ao corpo da Igreja, nem à unicidade 
e unidade da sociedade cristã, mas à hóstia consagrada. Com poucas excepções, esse continuou a ser, durante vários séculos, o significado oficial do "corpo místico", ao passo que a Igreja ou sociedade cristã continuava a ser conhecida como o corpus Christi, de acordo com a terminologia de São Paulo. Foi apenas num estranho e desconcertante desenvolvimento - un curieux chassé-croisé - que, finalmente, por volta de meados do século XII, essas designações mudaram de significado [...] Ou seja, o termo paulino, que originariamente designava a Igreja Cristã, passava agora a designar a hóstia consagrada; inversamente, a noção de corpus mysticum, até aí usada para descrever a hóstia, foi gradualmente transferida - depois de 1150 - para a Igreja como corpo organizado da sociedade cristã unida no sacramento do Altar. Em suma, a expressão "corpo místico", que originariamente tivera um significado litúrgico e sacramental, assumiu uma conotação de sentido sociológico. Foi nesse sentido sociológico que, finalmente, Bonifácio VIII definiu a Igreja como "um corpo místico cuja cabeça é Cristo" (KANTOROWICZ, 1997, p. 195-196).

De acordo com Kantorowicz, se é verdade que o novo termo «corpus mysticum» vinculava o organismo "visível" da Igreja à esfera litúrgica anterior, ao mesmo tempo concebia a Igreja como um corpo político e legal, situando-a no mesmo nível dos corpos políticos seculares que então se começavam a confirmar como entidades auto-suficientes. Curiosamente, quando a Igreja e a burocracia eclesial se consolidaram como «corpo político de Cristo», o sector do mundo secular proclamou-se como «sacro Império». Com efeito, segundo Kantorowicz, «o corpus mysticum espiritual e o sacrum imperium secular surgem simultaneamente - por volta da segunda metade do século XII» (KANTOROWICZ, 1997, p. 197). Tal corresponde a um daqueles momentos de imitação recíproca entre o papado e o império que Kantorowicz tão bem apresenta e analisa, quer na sua obra Os dois corpos do rei, quer num seu estudo dedicado aos «mistérios do Estado» ${ }^{11}$.

Com efeito, no ensaio «Mistérios do Estado. Um conceito absolutista e as suas origens na Baixa Idade Média», Kantorowicz sublinha

11 Sobre a transformação histórica do conceito teológico tardo-medieval de «mistérios de Estado» no conceito jurídico protomoderno de «segredos de Estado», remetemos o leitor para o nosso estudo (BENTO, 2015). 
de modo assaz persuasivo o modo como, mediante um mimetismo recíproco, a imitatio imperii pelo poder espiritual era contrabalançada por uma imitatio sacerdotii por parte do poder secular. Do seu ponto de vista, a imitação recíproca de emblemas, símbolos, privilégios e prerrogativas e o intercâmbio de direitos honoríficos entre sacerdotium (pontífice coroado) e regnum (imperador mitrado) levaram a que no final da Idade Média o papado surgisse como «uma monarquia absoluta e racional assente numa base mística, enquanto na mesma altura o Estado tendia cada vez mais a tornar-se uma quase-Igreja e, sob outros aspectos, uma monarquia mística assente numa base racional» (KANTOROWICZ, 1998, p. 30).

Sob esta perspectiva, a secularização política de conceitos teológicos - e, em primeiro lugar, a secularização do conceito de «realeza» - é tanto mais importante quanto, no entender de Kantorowicz, a aplicação de uma linguagem teológica a instituições seculares teve como efeito uma, pode dizer-se, entronização ou divinização do Estado moderno. Para tal, terá contribuído o intercâmbio de vocabulário entre os comentadores canonistas e os comentadores civilistas - e, por vezes, a confusão, se não mesmo a indistinção dos respectivos léxicos - , o qual estaria na origem, segundo Kantorowicz, da figura jurídica medieval conhecida por «Mistérios de Estado». Segundo o nosso autor, foi precisamente desta troca de fórmulas entre o direito canónico e o direito romano que resultou aquela «lingua mezzo-teologica» dos juristas medievais que tornou possível a dignificação e a elevação do Estado à esfera religiosa e sobrenatural do «mistério». Observa Kantorowicz: «Os juristas de todas as especialidades recorriam livremente, sem escrúpulos ou inibições, a metáforas e comparações teológicas para desenvolver os seus pontos de vista em glosas e comentários jurídicos» (KANTOROWICZ, 1998, p. 31).

Como vínhamos dizendo, na segunda metade do século XII os teólogos e os canonistas passaram a distinguir entre os «dois corpos do Senhor» - um o «corpus verum» individual no altar, a hóstia, e, o outro, o «corpus mysticum» colectivo, a Igreja (KANTOROWICZ, 1998, p. 198).

Ernst Kantorowicz chama, neste passo, a atenção do leitor para o facto de a mudança terminológica pela qual a hóstia consagrada 
se tornara no «corpus naturale» e o corpo social da Igreja no «corpus mysticum» coincidir com o momento em que as doutrinas jurídicas da estrutura corporativa e orgânica da sociedade ganharam um notório ascendente, moldando de modo decisivo o pensamento político na Baixa Idade Média. Nas obras dos teólogos desse período, argumenta Kantorowicz, era um tal padrão orgânico e corporativo que fornecia a norma de interpretação do «corpus mysticum».

Ora, segundo Kantorowicz, foi São Tomás de Aquino quem primeiro aplicou o termo «corpo místico» à Igreja como fenómeno social. Na esteira de João de Salisbúria e de Isaac de Stella, o doutor angélico comparava o «corpus mysticum» ao corpo natural do homem. Apesar de respeitar a tradição segundo a qual o corpo místico pertencia à esfera litúrgica e sacramental, opondo-se deste modo ao «corpus verum» representado pela hóstia consagrada, São Tomás de Aquino permite-se uma certa liberdade de interpretação quando fala dos dois corpos de Cristo - o verdadeiro e o místico - sem qualquer referência ao pão eucarístico. O que isto, no fundo, quer dizer, observa Kantorowicz, é que o «corpus verum» deixou gradualmente de significar exclusivamente a «presença real» de Cristo no sacramento. Com efeito, na interpretação que Kantorowicz faz de certas passagens da Suma Teológica, o «corpo verdadeiro» de Cristo não significa já o Cristo eucarístico do altar, mas o Cristo como ser individual, físico e encarnado, cujo «corpo natural» se tornava, sociologicamente, no modelo do «corpo místico» supra-individual e colectivo da Igreja. Contudo, o símile antropomórfico que comparava a Igreja e os seus membros com um corpo humano era acompanhado por uma comparação mais específica, a saber: a Igreja como «corpus mysticum» era comparada com o corpo individual de Cristo, com o seu «corpus verum» ou «corpus naturale». Por conseguinte, remata Kantorowicz, o corpo natural individual de Cristo era compreendido nesta imagem antropomórfica como um organismo que adquiria funções sociais e corporativas.

O desenvolvimento deste símile e a mudança terminológica e conceptual que nele se cunha, não ficaram, porém, por aqui. Com efeito, Kantorowicz considera que com a elevação (ou com o rebaixamento, consoante a perspectiva que se adopte) do místico a jurídico é 
a própria noção de «corpus mysticum», até então uma noção estritamente sacramental, que se "seculariza". Ora, o significado político desta "secularização" só pode ser o de uma des-sacramentalização ou, por assim dizer, "estatalização" do «corpus mysticum» de Cristo, que passa de um simples «corpo» a uma «corporação»:

Até então, o costume havia sido o de falar da Igreja como o "corpo místico de Cristo" (corpus Christi mysticum) que apenas faz sentido em termos sacramentais. Agora, no entanto, a Igreja, que havia sido $o$ corpo místico de Cristo, tornava-se um corpo místico por direito próprio. $\mathrm{Ou}$ seja, o organismo Igreja tornava-se um "corpo místico" num sentido quase jurídico: uma corporação mística. A mudança na terminologia não foi introduzida por acaso. Significava apenas mais um passo de modo a permitir que a instituição corporativa clerical do corpus ecclesiae iuridicum coincidisse com o corpus ecclesiae mysticum e, com isso, "secularizasse" a noção de "corpo místico" (KANTOROWICZ, 1997, p. 201).

Esta coincidência entre o corpo jurídico da Igreja e o corpo místico da Igreja, que pode talvez ser entendida - se quisermos inverter os termos da fórmula usada por Carl Schmitt na sua polémica anti-protestante em A visibilidade da Igreja - como uma «compressão do jurídico no místico», só pôde acontecer porque o conceito litúrgico anterior de «corpus mysticum» se transformou numa noção organológica ou jurídica relativamente neutra. O teólogo católico francês Henri de Lubac, no seu estudo Corpus mysticum. L'eucharistie et l'Eglise au Moyen Age (1944), chamou justamente a esta transformação do litúrgico em jurídico uma «degeneração» do conceito de «corpus mysticum», uma «degeneração» que ele atribui à enorme influência política dos teólogos do Papa Bonifácio VIII:

É conhecido o uso - deveria talvez dizer-se o abuso - que, no plano das reivindicações de poder, alguns dos teólogos agrupados em torno de Bonifácio VIII vão fazer da expressão [corpus mysticum]. [...] Mas, ao aplicarem deste modo à ordem jurídica e social uma palavra cujas ressonâncias eram todas "místicas" e espirituais, a sua doutrina marcará uma espécie de degenerescência do corpus mysticum, expondo o poder 
eclesiástico aos ressentimentos dos príncipes e às polémicas dos seus teólogos (LUBAC, 2009, p. 130).

Contudo, até que aquela «compressão do jurídico no místico» se tornasse efectiva e, por assim dizer, canónica, foi preciso esperar pela guinada que São Tomás de Aquino fez sofrer ao aspecto litúrgico e sacramental que o conceito de «corpo místico» adquiriu desde a Igreja cristã primitiva até praticamente meados do século XIII, o assim chamado «século dos juristas». Observa Kantorowicz:

Esta última ligação com a esfera do altar foi, contudo, cortada quando Tomás de Aquino escreveu: 'Pode-se dizer que cabeça e membros, em conjunto, são como uma única pessoa mística'. Nada poderia ser mais surpreendente que esta substituição bona fide de corpus mysticum por persona mystica. Aqui, a materialidade misteriosa que o termo corpus mysticum ainda abrigava - quaisquer que possam ter sido as suas conotações -, foi abandonada: 'O corpus Christi foi transformado numa corporação de Cristo'. Foi trocado por uma abstracção jurídica, a 'pessoa mística', uma noção reminiscente, na verdade sinónima, de 'pessoa fictícia', a persona reprasentata ou ficta, que os juristas haviam introduzido no pensamento legal e que será encontrada na base de grande parte da teorização política da Baixa Idade Média (KANTOROWICZ, 1997, p. 201-202).

É particularmente significativo que Ernst Kantorowicz, em ordem a reforçar esta sua tese, cite no meio desta passagem uma frase de uma obra de Rudolph Sohm, Das altkatholische Kirchenrecht und das Dekret Gratians (MUNIQUE \& LEIPZIG, 1908, p. 582). Mas, o que diz Sohm, afinal, nesta curta frase que Kantorowicz decide isolar e citar no interior de uma glosa de São Tomás de Aquino que ele retoma de Henry Lubac, desenvolvendo-a? Repitamos: «Aus dem Körper Christi hat sich die Kirche in eine Körperschaft Christi verwandelt (A Igreja transformou o corpo de Cristo numa corporação de Cristo») (KANTOROWICZ, 1997, p. 202).

Mas, quem é, afinal, Rudolf Sohm? Sohm é um autor luterano a quem Carl Schmitt, em Catolicismo Romano e Forma Política, se refere por 
duas vezes - sem, contudo, chegar a citar a obra acima referida - do seguinte modo:

i) Em oposição à fundamentação liberal com base no privado, a formação jurídica da Igreja católica é publicista. Também isso pertence à sua essência representativa e lhe torna possível abraçar o religioso, nessa medida, juridicamente. Daí que um nobre protestante, Rudolf Sohm, pudesse definir a Igreja católica como algo essencialmente jurídico, com o que considerava a religiosidade cristã como essencialmente jurídica (SCHMITT, 1998, p. 42).

ii) A grande traição que se reprova à Igreja romana é que ela não compreende Cristo como um homem privado e o cristianismo como uma coisa privada e como uma pura interioridade, mas configura uma instituição visível. Rudolf Sohm julgava reconhecer o pecado original no jurídico; outros viram-no, mais grandiosa e profundamente, na vontade de domínio mundial (SCHMITT, 1998, p. 44).

Num estudo recentemente dado à estampa, Jennifer Rust vislumbra naquela citação que Ernst Kantorowicz faz de Rudolf Sohm uma «agenda anti-schmittiana» e uma resposta subliminar do autor de Os dois corpos do rei à «teologia política» de Carl Schmitt. Esta hipótese, em larga medida especulativa e difícil de fundamentar, não é, contudo, totalmente despicienda, embora não seja susceptível de uma efectiva comprovação. Com efeito, Jennifer Rust alega que Rudolf Sohm, nesta parte do texto de Os dois corpos do rei em que Ernst Kantorowicz transcreve uma frase da supracitada obra de Sohm, este último não se refere a Tomás de Aquino, não chegando sequer o teólogo luterano a tratar de maneira explícita o conceito de «corpus mysticum». Em vez disso, alega Rust, Sohm ter-se-ia limitado a sublinhar o modo como uma Igreja cristã, originariamente "sacramental" e "misteriosa", se transformou, no final do século XII, numa Igreja estruturada como qualquer outra comunidade secular. Damos a palavra a Jennifer Rust:

A citação que Kantorowicz faz de Sohm, uma figura controversa que Schmitt critica com severidade e em pormenor em várias obras importantes dos anos vinte, reforça consideravelmente a ideia de que nesta secção de Os dois corpos do rei, assim como em outros lugares, 
Kantorowicz está empenhado numa resposta subterrânea à visão da teologia política de Carl Schmitt. Enquanto Kantorowicz confia profundamente numa nova fonte católica para desenvolver a sua própria concepção da 'teologia política medieval' [a autora refere-se à obra Henri de Lubac Corpus mysticum. L'eucharistie et l'Eglise au Moyen Age (1944)], uma fonte desconhecida pelo Schmitt dos anos vinte, a referência a Sohm, uma figura sob muitos aspectos veementemente oposta a Schmitt, recorda-nos que Schmitt é um alvo de longa data daquela concepção. Ao invocar o nome de Sohm, Kantorowicz não se limita a apresentar uma história desinteressada, pois é Sohm que torna possível que mais tarde Kantorowicz dissolva como meras ficções as reivindicações de Schmitt de uma autoridade personalista da Igreja (RUST, 2012, p. 116).

Regresso a Os dois corpos do rei. Neste particular, a tese de Ernst Kantorowicz - uma tese, sem dúvida, de longo alcance, a qual, a nosso ver, não foi até hoje objecto de uma exploração adequada e de um desenvolvimento consequente - é a de que com a reformulação jurídica da base sacramental do «corpus Christi» a Igreja se transforma numa «pessoa» jurídica, deixando de ser apenas um mero «corpo» sacramental: ao aceder ao status de «corpus mysticum», o «corpus Christi» da Alta Idade Média transfigura-se, e, com essa transfiguração, é a própria Igreja que, na Baixa Idade Média, se transforma numa «persona mystica». A utilização progressiva da noção de «corpus mysticum» como sinónima de «corpus fictum», «corpus imaginatum», «corpus repraesentatum» e outras similares, terá aberto, segundo Kantorowicz, o caminho para a descrição da Igreja como «corporação» ou «pessoa» jurídica:

Os juristas chegavam, dessa forma, tal como os teólogos, a uma distinção entre corpus verum - o corpo tangível de uma pessoa individual - e corpus fictum, o colectivo corporativo intangível e existente apenas como uma ficção da jurisprudência. Portanto, por analogia com o emprego teológico, bem como em contraste com pessoas naturais, os juristas definiam as suas pessoas fictícias, não raras vezes, como "corpos místicos" (KANTOROWICZ, 1997, p. 209). 
As consequências práticas desta mudança terminológica são claras para Ernst Kantorowicz. Na medida em que a Igreja passa a ser considerada como possuindo um governo similar ao de qualquer corporação secular, é o próprio conceito de «corpus mysticum» que se vê carregado de um conteúdo político secular. Deste modo, o «corpus mysticum», um conceito originariamente litúrgico, que antes significara o Sacramento do Altar, passa de ora em diante a significar o corpo político, ou «corpus iuridicum» da Igreja, e a ser usado na Igreja hierárquica sobretudo como um meio de exaltar a posição política do Papa: «Tal como todos os membros do corpo natural se referem à cabeça, assim também todos os fiéis do corpo místico da Igreja se referem à cabeça da Igreja, o Pontífice Romano» (KANTOROWICZ, 1997, p. 203).

Paulatinamente, considera Ernst Kantorowicz, o conceito de «corpus mysticum» perde grande parte do seu significado transcendental, vindo a ser "secularizado" e politizado pela própria Igreja e no interior da Igreja, até que, finalmente, passou a ser um oportuno símile de que os teóricos do Estado secular nascente se apropriaram, manipulando-o, de modo a dotarem as instituições do emergente Leviatão de uma certa auréola e magnificência religiosas. Com o passar do tempo, o conceito de «corpus mysticum» veio, portanto, apenas a significar a Igreja como um corpo político, ou, por transferência, qualquer outro corpo político do mundo secular. Não é, portanto, de admirar que ele se tenha tornado numa oportuna e apetecível presa do pensamento dos estadistas, juristas e académicos que então começavam a edificar e a desenvolver as bases das novas doutrinas dos Estados territoriais e seculares nascentes. Do «corpus ecclesiae mysticum» ao «corpus reipublicae mysticum», do corpo místico da Igreja ao corpo místico do Estado, foi um passo muito curto, mas foi, evidentemente, um passo necessário e certamente também um passo de longo alcance, repleto de consequências, pois uma vez articulada pela Igreja a ideia de uma comunidade política assente num «corpo místico», não restou ao Estado secular senão seguir e desenvolver essa noção até ao extremo, respondendo pelo estabelecimento de um contra-tipo. Assim, observa Kantorowicz, a fórmula teológico-política «o corpo místico da Igreja cuja cabeça é o Papa» foi facilmente 
substituída pela fórmula jurídica «o corpo místico da respublica cuja cabeça é o Príncipe»:

O novo Estado territorial e quase nacional, auto-suficiente, segundo as suas proclamações, e independente da Igreja e do Papado, extraía a sua riqueza das noções eclesiásticas, de manipulação tão conveniente, e, por fim, continuava a afirmar-se colocando a sua própria efemeridade ao mesmo nível da sempiternidade da Igreja militante. Neste processo, a ideia do corpus mysticum, assim como outras doutrinas corporativistas desenvolvidas pela Igreja, haveriam de ser de capital importância (KANTOROWICZ, 1997, p. 207).

Contudo, apesar das analogias existentes entre a Igreja e o Estado, ou apesar das apropriações, pelo Estado secular, das fórmulas eclesiais, há que sublinhar e deixar claro que até ao final do século XIII a ideia de um Estado existindo apenas em função de si mesmo era uma ideia estranha, uma ideia, por assim dizer, sem pés para caminhar por si mesma. E apesar de São Tomás de Aquino ter utilizado, como alternativa a "corpus mysticum», a heterodoxa expressão «persona mystica», antecipando já a substituição do jargão litúrgico pelo jargão jurídico, será necessário esperar quase três séculos até que o Estado, mormente sob a fórmula hobbesiana do Leviatão, seja finalmente «personificado». Com efeito, e Kantorowicz não se cansa de o sublinhar, até então o Estado não era uma pessoa fictícia, mas um todo orgânico ou organológico:

Para o dizer de forma sucinta, o regnum ou patria não era "personificado" (personified) - era "corporificado" (bodified). É sobretudo porque o Estado podia ser concebido como um "corpo", que se podia construir a analogia com o corpo místico da Igreja. O paralelo, por assim dizer, articulava-se com a palavra corpus, e não com a palavra persona, tal como os teólogos reflectiam sobre o duplex corpus Christi, e não sobre a duplex persona Christ - o que, de qualquer modo, teria sido um tanto ou quanto nestoriano (KANTOROWICZ, 1997, 270-271).

Concluiremos dizendo que não foi de pouca monta o esforço de Ernst Kantorowicz ao introduzir-nos, de uma maneira inédita, 
nos meandros teológicos que presidiram à formação e organização do Estado moderno tal como ainda hoje o podemos reconhecer em alguns dos seus aspectos mais decisivos. A monumental obra Os dois corpos do Rei permanece, a este título, um guia insubstituível e difícil de ultrapassar.

\section{Referências}

AGAMBEN, G. O Reino e a Glória. Uma genealogia teológica da economia e do governo. São Paulo: Boitempo Editorial, 2011.

ASSMANN, J. Poder y salvación. Teología y política en el Antiguo Egipto, Israel y Europa. Madrid: Abada Editores, 2015.

BENTO, A. Ernst H. Kantorowicz (1895-1963) and Gabriel Naudé (1600-1653): From "Mysteries of State" to "Coups d'État". In: PAVÓN BENITO, J. (ed.). Rewriting the Middle Ages in the Twentieth Century. Turnhout, Belgium: Brepols, 2015. p. 13-25.

BOURDIN, B. Préface. In: PETERSON, E. Le monothéisme: un problème politique et autres traités. Paris : Bayard, 2007. p. 7-43.

BOUREAU, A. Histoires d'un historien. Kantorowicz. Paris : Éditions Gallimard, 1990.

CERTEAU, M. de. La fable mystique, I (XVI-XVII siècle). Paris : Gallimard, 1982.

COLONGE, P. La crise religieuse de la République de Weimar. In : BLAQUART, J.-L. ; BOURDIN, B. (ed.). Théologie et politique: une relation ambivalente. Origine et actualisation d'un problème. Paris : L'Harmattan, 2009. p. 25-30.

DELEUZE, G. Critique et clinique. Paris : Les Éditions de Minuit, 1993.

DUSO, G. La Rappresentanza Politica. Genesi e crisi del concetto. Milão: Franco Angeli, 2003.

GALLI, C. Genealogia della politica. Carl Schmitt e la crisi del pensiero politico moderno. Bologna: Il Mulino, 1996. 
HARNACK, A. von. L'essence du christianisme. Seize conférences prononcés a l’Université de Berlin devant les étudiants de toutes les Facultés en 1899-1900. Paris : Librairie Fischbacher, 1907.

KAFKA, F. Considerações sobre o pecado, o sofrimento, a esperança e o verdadeiro caminho. Lisboa: Hiena Editora, 1992.

KANTOROWICZ, E. Selected Studies. J. J. New York: Augustin Publisher, 1965. KANTOROWICZ, E. The King's Two Bodies. A Study in Mediaeval Political Theology. Princeton: Princeton University Press, 1997.

KANTOROWICZ, E. Mistérios do Estado. Um conceito absolutista e as suas origens na Baixa Idade Média. In: Morrer pela Pátria. Lisboa: Edições João Sá da Costa, 1998.

LAWRENCE, D. H. Amor no feno e outros contos. Lisboa: Editora Assírio \& Alvim, 1988.

LUBAC, H. de. Corpus mysticum. L'eucharistie et l'Eglise au Moyen Age. Paris : Les Éditions du Cerf, 2009.

PETERSON, E. Theologische Traktate: Ausgewälthe Schriften I. Würzburg: Echter Verlag, 1994.

RUST, J. Political Theologies of the Corpus Mysticum: Schmitt, Kantorowicz, and de Lubac. In: HAMMIL, G.; LUPTON, J. R. (ed.). Political Theology and Early Modernity. Chicago: The University of Chicago Press, 2012.

SCHMITT, C. Die Sichtbarkeit der Kirche. Eine Scholastische Erwägung. In: Summa. Hellerau: Hellerauer Verlag Jakobhegner, 1917. p. 71-80.

SCHMITT, C. Römischer Katholizismus und Politische. Stuttgart: Ernst Klett Verlag, 1984.

SCHMITT, C. Verfassungslehre. Berlin: Duncker \& Humblot, 1993.

SCHMITT, C. Politische Theologie. Vier Kapitel zur Lehre von der Souveränität. Berlin: Duncker \& Humblot, 1996. 
434 BENTO, A.

SCHMITT, C. Catolicismo Romano e Forma Política. Trad. Alexandre Franco de Sá. Lisboa: Huguin Editores, 1998.

Recebido: 15/04/2017

Received: 04/15/2017

Aprovado: $18 / 07 / 2017$

Approved: 07/18/2017 